\title{
Hydrochemical assessment of the Beeshazar and associated lakes in Central Nepal
}

\author{
Ramesh Raj Pant ${ }^{1}$. Tarka Bahadur Chalaune ${ }^{1}$. Alina Dangol ${ }^{1} \cdot$ Yam Prasad Dhital ${ }^{2}$. Motee Lal Sharma ${ }^{3}$. \\ Khadka Bahadur Pal ${ }^{4} \cdot$ Syed Tallataf H. Shah ${ }^{5} \cdot$ Ashok Kumar Shrestha $^{6} \cdot$ Lal B. Thapa $^{7}$
}

Received: 25 June 2020 / Accepted: 19 December 2020 / Published online: 8 January 2021

(c) The Author(s) $2021 \quad$ OPEN

\begin{abstract}
Water quality deterioration has threatened aquatic life around the world including Nepal, which has been a serious issue for environmental sustainability and economic development. This study evaluated and interpreted hydrochemical parameters of the Beeshazar and associated lakes in Central Himalaya, Nepal. The study revealed that the water in the lake was slightly alkaline as the average $\mathrm{pH}$ was 7.52. The correlation and principal component analysis (PCA) identified both geogenic and anthropogenic processes as the controlling factors of hydrochemistry whereas the cluster analysis (CA) showed relatively more pollution in the associated Laxmi Lake. Also, the water quality index (WQI) classified the water as "good" for drinking purposes (i.e., $\mathrm{WQI}=33.90$ ), while the pollution index (PI) values were characterized as sub-cleanness and slightly polluted. In general, both the WQI and PI signify that water in the lake complex is currently safe for drinking purposes. It is further confirmed from the comparative analysis of chemical variables with other lakes in the region, WHO and national water quality guidelines for aqua culture that the most of the analyzed water parameters exhibited relatively low concentrations and were within the prescribed guidelines. However, the elevated concentrations of $\mathrm{NO}_{3}{ }^{-}$ and $\mathrm{PO}_{4}{ }^{3-}$ may pose serious problems for retaining water quality in the future. The results could be considered for future planning and management of the Ramsar Lakes of the lowland areas in the Himalaya and also as a valuable reference for the freshwater researchers at the national and international levels.
\end{abstract}

Keywords Hydrochemical parameters · Multivariate techniques · Pollution index - Water quality index - Ramsar site

MSC code $91 \mathrm{~B} 76$

JEL code Q25

\section{Introduction}

Freshwater ecosystems hold hydrological and ecological importance because of their potential role in providing multiple services to the inhabitants and the environment
$[1,2]$. These ecosystems are considered as an indispensable component of the earth surface as they support and regulate climatic patterns, drinking and irrigation water quality, fishing, hydropower generation, ecotourism, soil formation, groundwater recharge, flood protection and

$\triangle$ Lal B. Thapa, Ial.thapa@cdbtu.edu.np; lal_thapa25@yahoo.com | ${ }^{1}$ Central Department of Environmental Science, Institute of Science and Technology, Tribhuvan University, Kathmandu, Nepal. ${ }^{2}$ Institute of Eco-Chongming, Faculty of Earth Sciences, East China Normal University, Shanghai, China. ${ }^{3}$ Central Department of Chemistry, Institute of Science and Technology, Tribhuvan University, Kathmandu, Nepal. ${ }^{4}$ Tri-Chandra Multiple Campus, Tribhuvan University, Kathmandu, Nepal. ${ }^{5}$ Department of Earth Sciences, COMSATs University Islamabad- Abbottabad Campus, Abbottabad, Pakistan. ${ }^{6}$ Saptagandaki Multiple Campus, Bharatpur, Chitwan, Nepal. ${ }^{7}$ Central Department of Botany, Institute of Science and Technology, Tribhuvan University, Kathmandu, Nepal. 
other services for sustaining the human and environmental health [3]. Globally, the lake ecosystem may exist naturally or manmade and pollution in the lake water has become a rising environmental concern. There are various point and non-point sources of the pollutants including excessive nutrient contents, organic chemicals, toxic and trace metals and pesticide residues that are responsible for the deterioration of water quality in the lake ecosystems $[4,5]$. Domestic, agriculture, urban and industrial activities are considered to be the major sources of pollutants to the lake ecosystems [6]. In addition, lake characteristics such as homogeneity, heterogeneity, physiographic locations and land-use practices in the surrounding environments may also impact the spatial and temporal variations of water quality. For instance, shallow lakes are characterized by a high degree of heterogeneity in both spatial and temporal levels and are considered to be more sensitive towards the pollution sources, particularly caused by anthropogenic activities. Moreover, lakes are comparatively less dynamic and are readily susceptible to exogenic contaminants [7, 8].

Hydrochemistry of lake water has been widely used to characterize the water quality and source tracking of the chemical variables from natural processes such as rockweathering, evapo_crystallization, precipitation and contribution from the anthropogenic activities [9]. Various studies have been performed to assess the water quality and hydrochemistry of the lakes in Nepal and linked to local geology, climate and other environmental factors. Some of the works conducted in different lakes including Nagdaha [6]; Nainital, Sattal, Bhimtal and Naukuchiyatal [10]; Renuka lake [11]; Sella and Tsokyo Tso [12]; Begnas and Rupa [13]; Suraj, Sissu, Chandra and Deepak lakes [14]; Mansar [15]; Betkot lake [16] and Lake Qinghai catchments [17] exhibited the impacts of anthropogenic activities and global climate change on the hydrogeochemical dynamics. The Beeshazar and associated lakes are one of the major sources of water for drinking and irrigation purposes in the low land area of Central Nepal. As there is a Khageri Irrigation Canal passing through the vicinity of the lake cluster, the water quality of the lakes has great significance to the water quality of the Canal. The most of the aforementioned studies have focused general hydrochemistry but systematic chemical characterization of water quality concentrating on drinking and irrigational aspects using multivariate statistical analysis is limited. The novelty of this study is new insights on water quality of the Beeshazar and the associated lakes by using various chemical indices, principal component analysis (PCA) and cluster analysis (CA).

Wetlands being integrated systems are affected by changes in the key physical as well as chemical parameters of the hydrosphere at the catchment scale. Like many other regions in the world, the water quality in the lakes of Nepal is also found in the most vulnerable conditions. The wetlands located in the low land in Nepal are quite sensitive to global climate change and anthropogenic impacts including domestic, urban and industrial effluents and agricultural runoff [18-21]. The major threats in those lakes are sedimentation, invasion, eutrophication, encroachment and loss of water quality due to natural and anthropogenic inputs and the present study sites (the Beeshazar and associated lakes) are not the exceptions to the abovementioned issues. Therefore, the primary aim of this study is to evaluate the hydrochemistry and water quality status of the Ramsar listed Beeshazar and associated lakes in Central Himalaya, Nepal (Reference No. 1313) using multivariate statistical analysis. This study would have a great significance to formulate and implement water quality improvement programs for the sustainability of the lake complex. Additionally, the study could help to generate new knowledge and database on drinking and irrigational water quality in the Ramsar based lakes which need wide dissemination to the academic and policy perspectives.

\section{Materials and methods}

\subsection{Study area and site description}

The Beeshazar and associated lakes $\left(27.37^{\circ} \mathrm{N}\right.$ and $\left.84.26^{\circ} \mathrm{E}\right)$ are situated in the Ratnanagar Municipality, Chitwan district of Central Nepal (Fig. 1). The lake complex is $15 \mathrm{~km}$ away from the Narayanghat Bazaar and covers an area of about $32 \mathrm{~km}^{2}$ including mosaics of diverse habitats; open water bodies, marshes, swamps, grasslands and forests. The complex includes Beeshazar, Kumal, Laxmi, Kingfisher and Tikauli lakes. The complex has an open water area of about $1 \mathrm{~km}^{2}$ and represents one of the largest freshwater lake complex in the low land (Tarai) region of Nepal. Considering the ecological, economic and aesthetic importance of the lake complex, it has been included in the Ramsar list in 2003 [22].

The climate of the area is subtropical and characterized by two distinct climatic seasons namely summer and winter. The summer season extends from March to June, during which the maximum average day temperature is $35.1^{\circ} \mathrm{C}$ which falls to a minimum of $19.8^{\circ} \mathrm{C}$ at night. This area receives about $2000-2500 \mathrm{~mm}$ rainfall in a year and about $80 \%$ of the total annual rainfall occurs during the monsoon months between June and September [22].

The main recharge sources of water in the Beeshazar and associated lakes are the Khageri irrigation canal, rainwater and three major rivers that are the Narayani, Rapti and Reu with several small lakes, marshy lands and pools [22]. The soil and geological features of the area are 


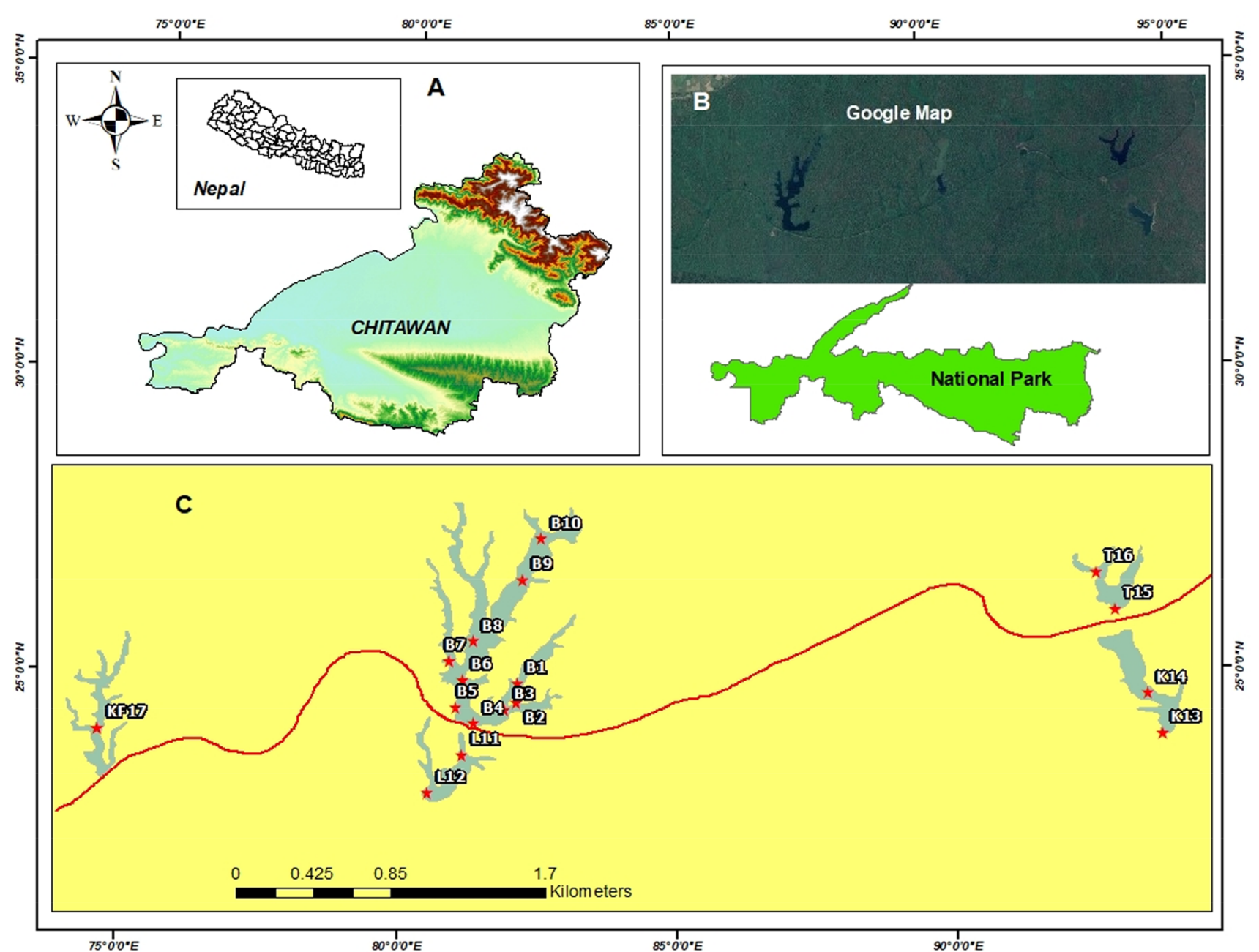

Fig. 1 Map of study area (Beeshazar and associated lakes, Chitwan, Nepal). A: Map of Nepal with Chitwan district, B: Chitwan National Park, C: Sampling sites in the study area

dominated by the alluvial deposits with sandy loam mixed with coarser soil particles and sediments containing boulder, gravel, silt and clay brought down during monsoon from high altitudes of the region. Due to extensive coverage of vegetation and dense forests, the soil of the lake area contains a high amount of humus. The surrounding area of the lake complex is characterized by subtropical forests dominated by Sal (Shorea robusta) and moist deciduous vegetation including grassland and riverine forests $[22,23]$.

\subsection{Sampling and analysis}

Sampling sites were selected in such a way to bear the maximum representation of the inlet, outlet and changing pattern of land use of the lake complex. Altogether 17 surface water samples were collected from the Beeshazar $(n=10)$; Laxmi, Kumal and Tikauli $(n=2$, from each); and
Kingfisher $(n=1)$ lakes on March 2016 (Fig. 1). The samples from different sites were collected in clean $1 \mathrm{~L}$ plastic bottles after rinsing with the same water from the collection site. The parameters like water temperature (WT), $\mathrm{pH}$, electrical conductivity (EC), total dissolved solids (TDS) and dissolved oxygen (DO) were measured in-situ by using a multi-parameter device (HI-98,129, HANNA, Romania) and DO meter immediately after the collection of the samples, whereas total hardness $(\mathrm{TH})$, ammonia $\left(\mathrm{NH}_{4}{ }^{+}\right)$, nitrate $\left(\mathrm{NO}_{3}{ }^{-}\right)$, phosphate $\left(\mathrm{PO}_{4}{ }^{3-}\right)$, chloride $\left(\mathrm{Cl}^{-}\right)$and alkalinity were analyzed in the laboratory of the Central Department of Environmental Science, Tribhuvan University, Nepal [24, 25].

The water samples were filtered using $0.45 \mathrm{~mm}$ Millipore membrane filters with a hand-operated vacuum pump. The raw samples were sealed in the sampling bottles and were preserved at $4{ }^{\circ} \mathrm{C}$ to avoid any major alteration for various hydrochemical analyses. The parameters 
of the collected water samples were analyzed as per the standard methods prescribed by APHA (2005) [24]. Chemical parameters $\mathrm{NO}_{3}{ }^{-}, \mathrm{PO}_{4}{ }^{3-}$ and $\mathrm{NH}_{4}{ }^{+}$were measured through phenol di-sulphonic acid method, stannous chloride method and phenate method using the spectrophotometer (model S2200) under $410 \mathrm{~nm}, 690 \mathrm{~nm}$ and $635 \mathrm{~nm}$, respectively. In addition, $\mathrm{Cl}^{-}$was measured by argentometric titration method, while the $\mathrm{TH}$ and alkalinity were analyzed by the titration method [14]. Highgrade chemical reagents were used for the analysis. Two field blanks were prepared with deionized water. Controls were performed on appropriate blank solutions. These blank samples were used in a spectrophotometer for the calibration. The results of blank samples displayed very negligible contamination during sampling and transportation of the samples. For quality control, special care was taken during sample collection and laboratory analyses following standard procedures $[1,23]$. The analytical precision was maintained using the known standard and it was within $\pm 15 \%$.

\subsection{Statistical analysis}

The descriptive statistics, correlation, principal component analysis (PCA) and cluster analysis (CA) were performed using statistical package for social sciences (SPSS) software (Version 21.0). A correlation matrix was applied to describe the degree of relationship between hydrochemical parameters. Spearman's correlation matrix was used to display the relationship between the variables. Multivariate analysis was performed by using CA and PCA techniques. Hierarchical agglomerative CA was performed on the normalized dataset using Ward's method with Euclidean distances to identify similar sites in the different study lakes. PCA of the normalized dataset was performed to classify the major sources and the controlling factors of the hydrochemical variables in the lake complex [1].

\subsection{Water quality analysis}

Water quality index (WQI) is one of the most effective ways of transforming a large number of hydrochemical datasets into a single numerical value to summarize the overall water quality [4]. The WQI was calculated as:

$\mathrm{WQI}=\Sigma(\mathrm{Ci} / \mathrm{Si} \times \mathrm{Wi}) \times 100$

where, $\mathrm{Wi}=\mathrm{wi} / \Sigma \mathrm{wi}$, wi is the weight of each parameter and $\Sigma w i$ is the sum of the weightings of all parameters. Here, $\mathrm{Ci}$ is the concentration of the chemical variable in each water sample and $\mathrm{Si}$ is the WHO guidelines for drinking water [26].
Similarly, the pollution index (PI) is a technique to assess the potential pollution load that contributes to the rating the water quality accurately and timely. The PI was calculated as [27]:

$\mathrm{PI}=1 / \mathrm{n} \sum_{\mathrm{i}=1}^{\mathrm{n}} \mathrm{Ci} / \mathrm{Si}$

$\mathrm{PI}=1 / \mathrm{n} \sum_{i=1}^{\mathrm{n}} \mathrm{Ci} / \mathrm{Si}$ where $\mathrm{PI}$ is a comprehensive pollution index, $\mathrm{Ci}$ is the measured concentration of the pollutant $(\mathrm{mg} / \mathrm{L}), \mathrm{Si}$ is the limits allowed by the WHO standard and $\mathrm{n}$ is the number of selected pollutants.

\section{Results and discussion}

\subsection{General hydrochemical patterns}

The statistical summary of the measured hydrochemical parameters in the Beeshazar and associated lakes of Chitwan, Nepal is presented in Table 1. The results are compared with WHO guidelines and also with the national water quality guidelines for aqua culture (NWQGAC), Nepal $[26,28]$. An increase in the WT may decrease the portability of water due to the high interaction of various chemicals and their reactivity $[21,29]$. The WT in the lake complex studied ranged from $24.90{ }^{\circ} \mathrm{C}$ to $30.70^{\circ} \mathrm{C}$ with an average value of $27.58 \pm 2.1^{\circ} \mathrm{C}$. It indicates that water is suitable for the chemical and biological functioning of aquatic organisms [6].

Generally, DO value should be about $6 \mathrm{mg} / \mathrm{L}$ for drinking purposes and $>4 \mathrm{mg} / \mathrm{L}$ for sustaining the healthy aquatic ecosystems including the metabolic activities of microorganisms [30]. In this study, the concentration of

Table 1 Statistical summary of hydrochemical parameters of the Beeshazar and associated lakes, Chitwan, Nepal

\begin{tabular}{llrll}
\hline Par & Range & \multicolumn{1}{c}{ Mean \pm SD } & NWQGAC & WHO (2011) limits \\
\hline WT & $24.9-30.7$ & $27.58 \pm 2.1$ & - & - \\
pH & $7-7.89$ & $7.52 \pm 0.3$ & $6.5-8.5$ & $6.5-8.5$ \\
EC & $52-123$ & $85 \pm 21.6$ & 1500 & 750 \\
TDS & $30-63$ & $49 \pm 10.8$ & 1000 & 600 \\
TH & $28-160$ & $59.52 \pm 36.4$ & 500 & 500 \\
Alk & $20-70$ & $34.41 \pm 12.97$ & - & 300 \\
Cl & $6.39-25.6$ & $12.78 \pm 5.24$ & 250 & 250 \\
$\mathrm{DO}^{-}$ & $4.26-6.69$ & $5.49 \pm 0.74$ & - & - \\
$\mathrm{NO}_{3}{ }^{-}$ & $0.23-6.67$ & $2.19 \pm 1.81$ & 50 & 50 \\
$\mathrm{PO}_{4}{ }^{3-}$ & $0.03-0.91$ & $0.42 \pm 0.26$ & - & 1.0 \\
$\mathrm{NH}_{4}^{+}$ & $0.04-0.09$ & $0.07 \pm 0.01$ & - & 1.5 \\
\hline
\end{tabular}

All the variables are expressed in $\mathrm{mg} / \mathrm{L}$, except $\mathrm{pH}, \mathrm{WT}\left({ }^{\circ} \mathrm{C}\right)$ and $\mathrm{EC}$ $(\mu \mathrm{S} / \mathrm{cm})$ 
DO varied from 4.26 to $6.69 \mathrm{mg} / \mathrm{L}$ which is within the permissible range for the survival and growth of the aquatic organisms. The present study recorded the average $\mathrm{pH}$ value of $7.52 \pm 0.26$, indicating the mildly alkaline water in the lake complex (Table 1). Regardless of the different locations, the $\mathrm{pH}$ values remain almost neutral to mild alkaline which satisfies the permissible limits of the NWQGAC and WHO guidelines [26, 28, 31].

Likewise, EC and TDS concentrations in our study were relatively low $(85 \pm 21.6 \mu \mathrm{S} / \mathrm{cm}$ and $49 \pm 10.8 \mathrm{mg} / \mathrm{L})$, respectively. These values were within the guidelines provided by NWQGAC and WHO, which may be attributed due to low salinity and mineral contents. The low ionic strength and TDS mainly contribute to the salinity of water and thus the $E C$ is a good indicator for salinity for getting the general insights of the lake complex [26, 28, 32]. Hence, the water of the lake complex is suitable for drinking purposes and also for the aquatic biota for their survival, growth and development.

Based on hardness, water can be categorized into soft water ( $<60 \mathrm{mg} / \mathrm{L})$, medium water $(60-119 \mathrm{mg} / \mathrm{L})$, hard water (120-180 mg/L) and very hard water ( $>180 \mathrm{mg} / \mathrm{L}$ ). The minimum concentration of TH was found in the Beeshazar Lake $(41 \mathrm{mg} / \mathrm{L})$ whereas the maximum concentration was found in the Laxmi Lake $(160 \mathrm{mg} / \mathrm{L})$ (Table 2). The TH in the study sites is within the prescribed guideline of NWQGAC and WHO and all the lakes have soft waters (except Laxmi Lake) $[26,28]$. Although the major cations are not separately analyzed in this study, the TH indicates that the inputs of $\mathrm{Ca}^{2+}$ and $\mathrm{Mg}^{2+}$ are relatively high in the lake complex [14]. Similarly, the values of alkalinity were ranged from 20 to $70 \mathrm{mg} / \mathrm{L}$ and suitable for domestic purposes and also characterizes the carbonatedominated lithology in the lake complex (Table 2).
The concentration of the $\mathrm{Cl}^{-}$was ranged from 6.39 to $25.6 \mathrm{mg} / \mathrm{L}$ (Table 2), which is lower than the WHO maximum permissible limit [26]. It indicates that the contribution of atmospheric inputs and anthropogenic sources (e.g., inorganic fertilizers and sewers) have a relatively minor contribution to $\mathrm{Cl}^{-}$contents in the lake complex. The concentrations of $\mathrm{NO}_{3}{ }^{-}$and $\mathrm{NH}_{4}{ }^{+}$were observed between the range of 0.23 to $6.67 \mathrm{mg} / \mathrm{L}$ (mean: $2.19 \pm 1.81$ ) and 0.04 to $0.09 \mathrm{mg} / \mathrm{L}$ (mean: $0.07 \pm 0.01 \mathrm{mg} / \mathrm{L}$ ), respectively (Table 2). Both of the $\mathrm{NO}_{3}{ }^{-}$and $\mathrm{NH}_{4}{ }^{+}$were within the permissible range of recommended values and overall low anthropogenic interferences in the lake complex. However, the maximum concentration of $\mathrm{NO}_{3}{ }^{-}$was found to be $6.67 \mathrm{mg} / \mathrm{L}$ (Table 2), signifying the spatial discrimination in terms of anthropogenic contaminations in the lake complex. The high concentration of $\mathrm{NO}_{3}{ }^{-}$in some of the sampling points could be attributed due to agriculture runoffs, as there is intensive farming in the vicinity of the lake complex [33].

The mean concentration of $\mathrm{PO}_{4}{ }^{3-}$ was found to be $0.42 \pm 0.26 \mathrm{mg} / \mathrm{L}$. Relatively high concentrations of $\mathrm{PO}_{4}{ }^{3-}$ were found in some of the sampling points, indicating the site-specific anthropogenic signature in the lake complex. Although underlying lake sediments and alluvial soil deposits are the main sources of phosphorus, the elevated concentrations of the $\mathrm{PO}_{4}{ }^{3-}$ in the lake complex were supposed to be contributed from the farmlands in surrounding areas [21].

\subsection{Spatial patterns of hydrochemical parameters}

The descriptive statistics of hydrochemical parameters at the study lake complex are shown in Table 2 and Fig. 2. The mean $\mathrm{pH}$ values of all the studied lakes were found to be neutral to the slightly alkaline with a negligible

Table 2 Spatial variation in hydrochemical parameters of the Beeshazar and associated lakes, Chitwan, Nepal

\begin{tabular}{|c|c|c|c|c|c|c|c|c|c|}
\hline \multirow[t]{2}{*}{ Par } & \multicolumn{2}{|l|}{ Beeshazar } & \multicolumn{2}{|l|}{ Laxmi } & \multicolumn{2}{|l|}{ Kumal } & \multicolumn{2}{|l|}{ Tikauli } & \multirow[t]{2}{*}{ Kingfisher } \\
\hline & Range & Mean \pm SD & Range & Mean \pm SD & Range & Mean \pm SD & Range & Mean \pm SD & \\
\hline WT & $24.9-29.5$ & $26.15 \pm 13$ & $29.6-30.7$ & $30.1 \pm 0.78$ & $29.4-29.5$ & $29.45 \pm 0.07$ & $29.8-29.9$ & $29.85 \pm 0.07$ & 29.90 \\
\hline $\mathrm{pH}$ & $7-7.89$ & $7.55 \pm 0.32$ & $7.2-7.68$ & $7.44 \pm 0.34$ & $7.5-7.6$ & $7.55 \pm 0.07$ & 7.3-7.76 & $7.53 \pm 0.33$ & 7.76 \\
\hline $\mathrm{EC}$ & $52-101$ & $84 \pm 18.68$ & $121-123$ & $122 \pm 0.35$ & $68-71$ & $69 \pm 1.77$ & $77-86$ & $82 \pm 6.65$ & 86.00 \\
\hline TDS & $30-63$ & $50 \pm 11.4$ & $60-62$ & $61 \pm 0.18$ & $40.9-42$ & $42 \pm 0.92$ & $46-52$ & $49 \pm 4$ & 52.00 \\
\hline $\mathrm{TH}$ & $41-53$ & $47.2 \pm 5.8$ & $150-160$ & $155 \pm 7.07$ & $46-50$ & $48 \pm 2.83$ & $52-54$ & $53 \pm 1.41$ & 52.00 \\
\hline Alkalinity & $25-70$ & $39.5 \pm 13.8$ & $20-30$ & $25 \pm 7.1$ & $20-30$ & $25 \pm 7.07$ & $20-30$ & $25 \pm 7.07$ & 20.00 \\
\hline $\mathrm{Cl}^{-}$ & $6.39-14.2$ & $9.02 \pm 2.2$ & $17-25.6$ & $21.3 \pm 3$ & $8.52-1136$ & $9.94 \pm 2.01$ & $11.36-12.78$ & $12.07 \pm 1$ & 12.78 \\
\hline DO & $4.26-6.69$ & $5.26 \pm 0.74$ & $4.86-5.88$ & $5.37 \pm 0.72$ & $6.08-6.28$ & $6.18 \pm 0.14$ & $4.86-6.28$ & $5.57 \pm 1$ & 6.28 \\
\hline $\mathrm{NO}_{3}^{-}$ & $0.23-4.09$ & $1.75 \pm 1.14$ & $5.85-6.67$ & $6.67 \pm 0.58$ & $1.04-2.68$ & $1.86 \pm 1.16$ & $1.02-1.89$ & $1.46 \pm 0.62$ & 1.02 \\
\hline $\mathrm{PO}_{4}^{3-}$ & $0.03-0.81$ & $0.34 \pm 0.24$ & $0.74-0.81$ & $0.78 \pm 0.05$ & $0.38-0.54$ & $0.46 \pm 0.11$ & $0.23-0.91$ & $0.57 \pm 0.48$ & 0.23 \\
\hline $\mathrm{NH}_{4}^{+}$ & $0.07-0.08$ & $0.07 \pm 0$ & 0.07 & $0.07 \pm 0$ & $0.06-0.09$ & $0.08 \pm 0.02$ & $0.04-0.08$ & $0.06 \pm 0.03$ & 0.04 \\
\hline
\end{tabular}




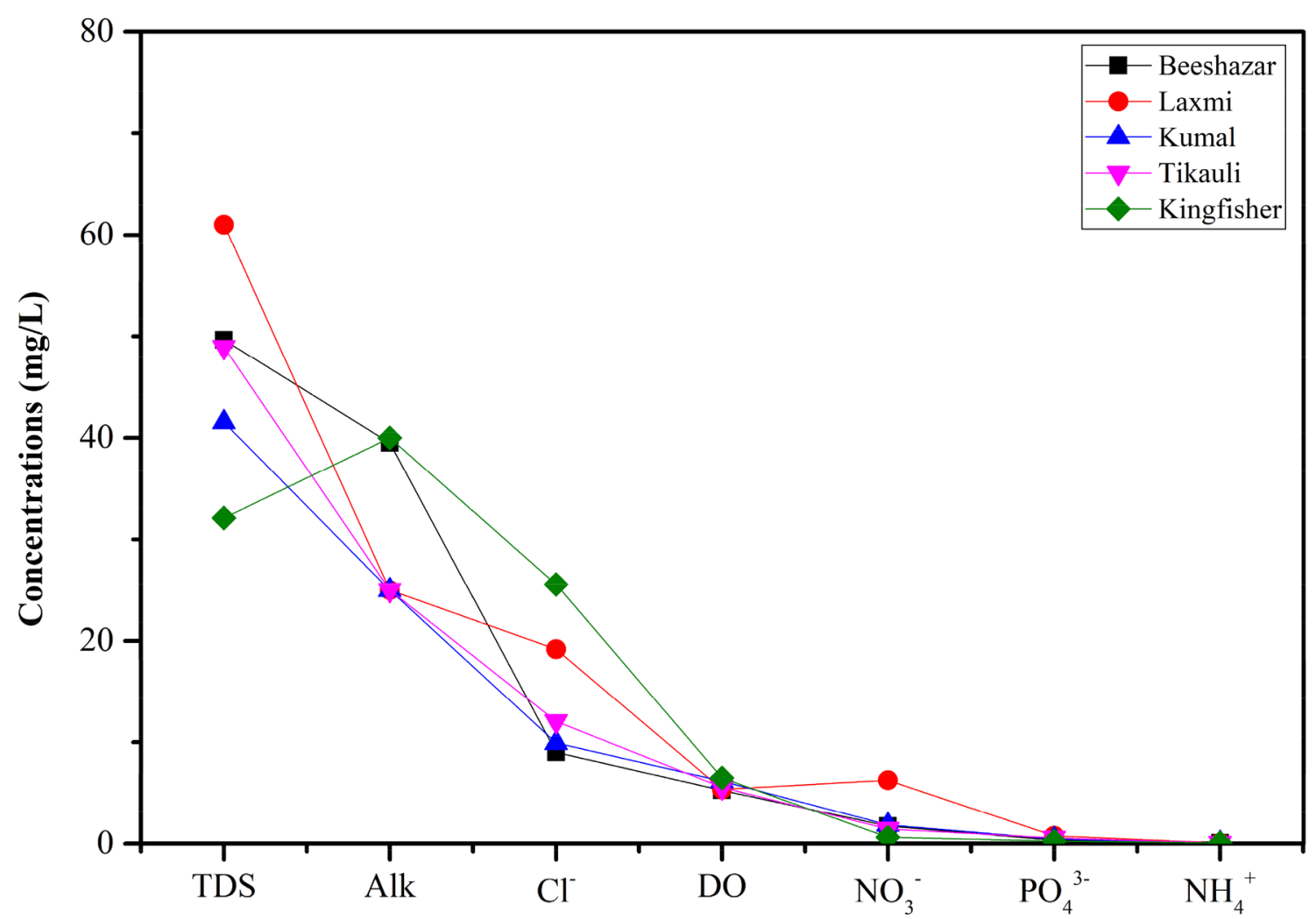

Fig. 2 Spatial patterns of hydro-chemical parameters in the Beeshazar and associated lakes, Chitwan, Nepal

variation. Similarly, the average temperature of the lakes was obtained within the desirable limits. However, EC and TDS displayed a substantial spatial variability in the different lakes. For instance, the mean concentration of EC and TDS was found to be elevated in the Laxmi Lake compared to the other lakes which might be due to the low outflow rate of water and interferences of agricultural runoff and activities of wild animals [34]. These results are also supported by the high concentrations of nitrate in Laxmi Lake (Fig. 2). Similarly, the mean value of TH in Laxmi Lake was found relatively higher than the other lakes, indicating the higher carbonate weathering with more anthropogenic interference in the lake. The higher concentration of TH in the Laxmi Lake is also consistent with the results of EC and TDS. Results showed that the mean value of DO was found in the order of Kingfisher $>$ Kumal $>$ Tikauli $>$ Laxmi $>$ Beeshazaar. The higher value of $\mathrm{DO}$ in the water designates the better water quality, thus, the aforementioned order of the lakes also characterizes the spatial water quality variations in the lake complex [35].

Similarly, the mean $\mathrm{Cl}^{-}$values of different lakes were reported in the order of Laxmi > Kingfisher $>$ Tikauli $>$ Kumal $>$ Beeshazar. The relatively high $\mathrm{Cl}^{-}$content in the Laxmi Lake indicates the higher ionic strength, which may be resulting from the leaching of soil salts due to intensive agricultural practices in the vicinity of the lake complex. Besides, the order of mean concentrations of $\mathrm{NO}_{3}{ }^{-}$and $\mathrm{NH}_{4}{ }_{4}$ in the studied lakes were found to be Laxmi > Kumal > Beeshazar > Tikauli > Kingfisher; and Kumal $>$ Beeshazar $>$ Laxmi $>$ Tikauli $>$ Kingfisher, respectively. The high concentration of $\mathrm{NO}_{3}{ }^{-}$in the Laxmi Lake was again characterized by intensive agriculture activities in the surrounding areas [33]. The findings showed that the mean concentration of $\mathrm{PO}_{4}{ }^{3-}$ was found in the order of Laxmi > Tikauli > Kumal > Beeshazar > Kingfisher Lakes. From all these analyses, it was found that the Laxmi Lake has a relatively high pollution load as compared to the other lakes (Fig. 2).

\subsection{Cluster analysis (CA)}

A dendrogram with hierarchial clustering based on $\mathrm{EC}$, TDS, $\mathrm{TH}$, alkalinity, $\mathrm{Cl}^{-}, \mathrm{NO}_{3}{ }^{-}, \mathrm{PO}_{4}{ }^{3-}$ and $\mathrm{NH}_{4}{ }^{+}$revealed that the sampling sites into 3 distinctive clusters exhibiting their pollution magnitudes as clean, slightly polluted and polluted (Fig. 3). Cluster 1 corresponding to sites 1 , 4, 5, 6, 9 and 10 represents less pollution than the other sites. All of these sampling points were from the main Beeshazar Lake. Cluster 2 includes the sites 2, 3, 7, 8, 13, 


\section{Dendrogram using Ward Linkage}

Rescaled Distance Cluster Combine

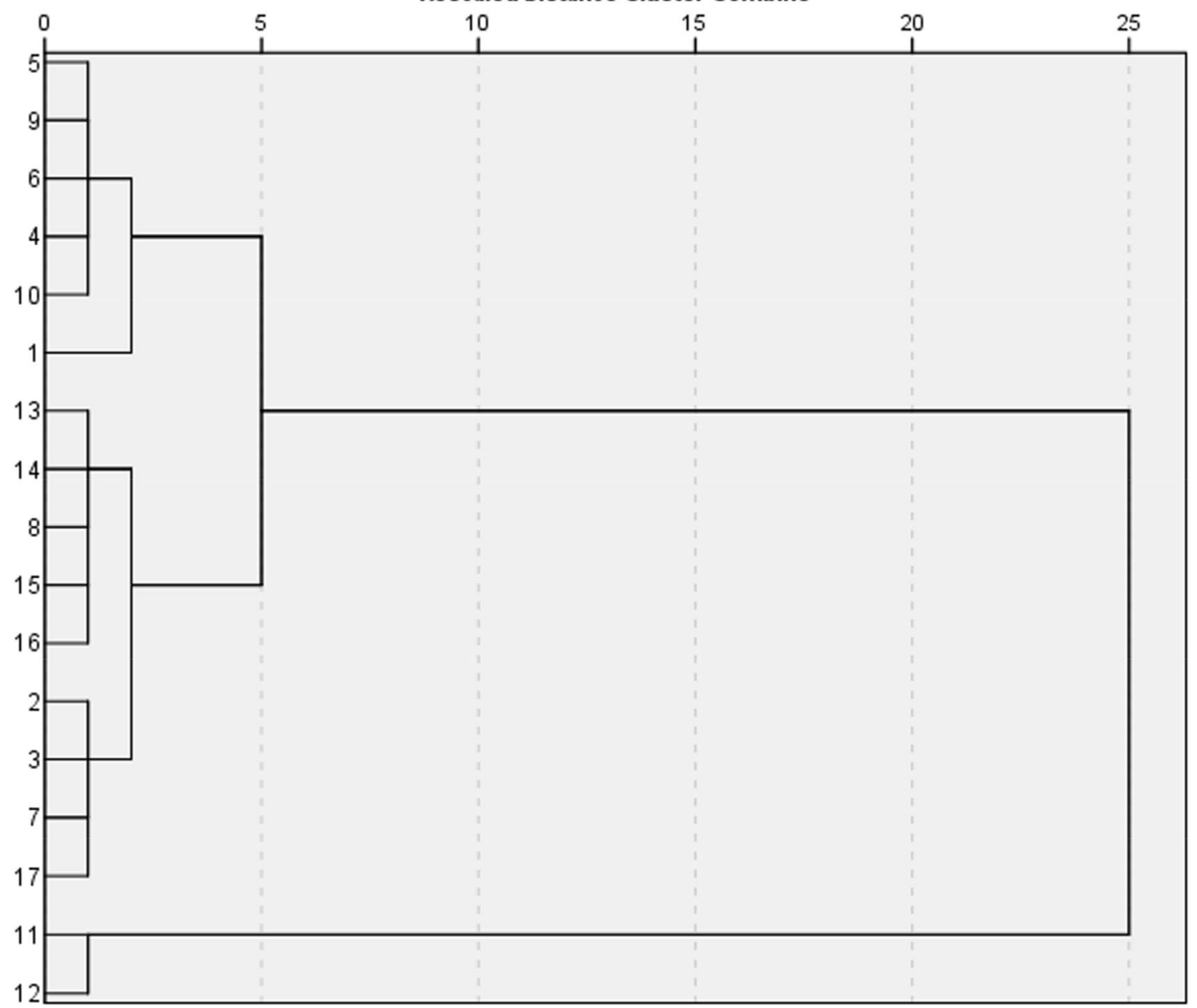

Fig. 3 Dendrogram based on hierarchical cluster of sampling sites of the Beeshazar and associated lakes, Chitwan, Nepal. (Sites: 1 to 10 represent $B 1$ to $B 10,11$ and 12 represent $L 11$ and $L 12,13$ and

$14,15,16$ and 17 and are slightly polluted than Cluster 1 , might be due to agricultural runoff and high wildlife recreational activities [36]. These sampling points were located from the Beeshazar, Kumal, Tikauli and Kingfisher lakes. Similarly, the Cluster 3 contains just two sites (11 and 12) from the Laxmi Lake which was characerized by presence of algal blooms and human disturbance, especially agricultural runoff. Additionally, anthropic activities are found in this area from the perspective of recreation and research activities. The $C A$ results showed that the Clusters 1 and 2 have better water quality than the Cluster 3, which are consistent with the results given by the spatial variations as shown in Fig. 2.
14 represents $\mathrm{K} 13$ and $\mathrm{K} 14,15$ and 16 represents $\mathrm{T} 15$ and T16, and 17 represents KF17)

\subsection{Principal component analysis (PCA)}

The PCA was executed for EC, TDS, TH, alkalinity, $\mathrm{Cl}^{-}$, $\mathrm{NO}_{3}{ }^{-}, \mathrm{PO}_{4}{ }^{3-}$ and $\mathrm{NH}_{4}{ }^{+}$and the results were interpreted on the basis of factor loadings (eigenvalues $>1$ ). Studied hydrochemical variables were categorized into 4 principal components (PC1, PC2, PC3 and PC4) in the loading plot (Fig. 4). The PCA results can be classified as strong, moderate and weak, if the factor loadings are $>0.75$, $0.75-0.50$ and $0.50-0.30$, respectively $[1,36]$. The test results suggested that the PCA can be significant in the present study [Kaiser-Meyer-Olkin $(K M O)=0.62$ ]. The result of the analysis of water quality parameters based on PCA is shown in Table 3. The PC1 clarifies the strong positive loadings on EC and TDS, with $34.43 \%$ of the total variance and moderate positive loadings on 
Fig. 4 Loading plots for the principal component of the monitoring data of the hydro-chemical variables of the Beeshazar and associated lakes, Chitwan Nepal

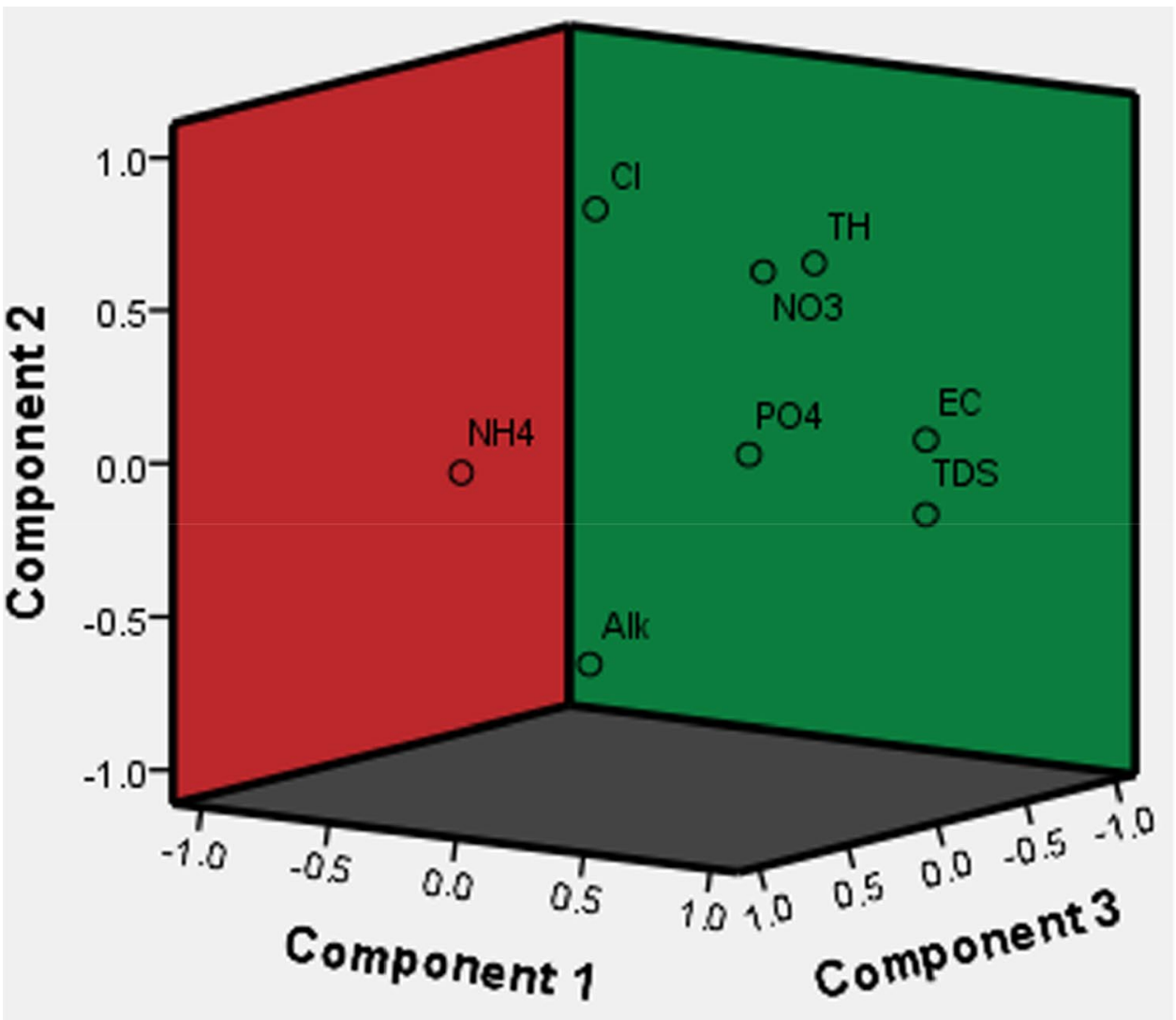

Table 3 Component matrix of hydrochemical dataset of the Beeshazar and associated lakes, Chitwan, Nepal

\begin{tabular}{llrll}
\hline Factors & \multicolumn{4}{l}{ Rotated component matrix } \\
\cline { 2 - 5 } & PC 1 & PC 2 & PC 3 & PC 4 \\
\hline $\mathrm{pH}$ & -0.20 & 0.16 & -0.86 & -0.19 \\
$\mathrm{EC}$ & $\mathbf{0 . 9 4}$ & 0.07 & -0.07 & -0.18 \\
$\mathrm{TDS}$ & $\mathbf{0 . 9 0}$ & -0.16 & 0.00 & -0.25 \\
$\mathrm{TH}$ & $\mathbf{0 . 6 9}$ & $\mathbf{0 . 6 3}$ & -0.03 & 0.07 \\
$\mathrm{Alkalinity}$ & 0.03 & $-\mathbf{0 . 6 8}$ & 0.22 & 0.37 \\
$\mathrm{Cl}^{-}$ & -0.04 & $\mathbf{0 . 7 8}$ & 0.29 & 0.17 \\
$\mathrm{DO}^{-}$ & -0.27 & 0.20 & $\mathbf{0 . 8 0}$ & -0.22 \\
$\mathrm{NO}_{3}{ }^{-}$ & $\mathbf{0 . 5 8}$ & $\mathbf{0 . 5 0}$ & -0.17 & 0.22 \\
$\mathrm{PO}_{4}{ }^{3-}$ & $\mathbf{0 . 7 0}$ & 0.08 & 0.12 & 0.41 \\
$\mathrm{NH}_{4}{ }^{+}$ & -0.12 & 0.02 & -0.02 & $\mathbf{0 . 8 9}$ \\
Eigenvalues & 3.44 & 1.74 & 1.60 & 1.31 \\
Variance (\%) & 34.43 & 17.39 & 15.96 & 13.08 \\
Cumulative \% $^{-}$ & $\mathbf{3 4 . 4 3}$ & $\mathbf{5 1 . 8 2}$ & $\mathbf{6 7 . 7 8}$ & $\mathbf{8 0 . 8 6}$ \\
\hline
\end{tabular}

$\mathrm{TH}, \mathrm{PO}_{4}{ }^{3-}$ and $\mathrm{NO}_{3}{ }^{-}$. Generally, a higher value of the $\mathrm{EC}$ shows high values of TDS due to more concentrations of dissolved ions. In these results, moderate ionic strength was reflected by EC in all the lakes and the analyzed ions have either moderate or weak positive or negative association with EC and TDS. This is due to the reason that some of the major ions that could have a major influence on EC and TDS are not analyzed.

PC2 explains $17.39 \%$ of the total variance and strong positive loading on $\mathrm{Cl}^{-}$and moderate positive loading on $\mathrm{TH}, \mathrm{NO}_{3}{ }^{-}$and moderate negative loading on alkalinity (Alk). It indicates that $\mathrm{Cl}^{-}, \mathrm{NO}_{3}{ }^{-}$and $\mathrm{TH}$ are contributing to the same sources, whereas the alkalinity source could be different. From the results, it is clear that $\mathrm{Cl}^{-}$, $\mathrm{NO}_{3}{ }^{-}$and $\mathrm{TH}$ could be contributed from mixed geogenic and anthropogenic sources, whereas the prime source of alkalinity could be the weathering of carbonate dominated underlying lithology in the lake complex. The PC3 explains $15.96 \%$ of the total variance and strong positive loading on DO, signifying that the major sources of DO in the lake complex are distinct from the other chemical variables. Lastly, the PC4 elucidates $13.08 \%$ of total variance with strong loading on $\mathrm{NH}_{4}{ }^{+}$, suggesting that the different origins of ammonium compounds from other sources. Since the lake complex is surrounded by dense forest with a huge accumulation of leaf litter, the decomposition of the nitrogenous compounds and organic matters by heterotrophic bacteria could be the primary source of $\mathrm{NH}_{4}{ }^{+}$in the lakes. 


\subsection{Correlation analysis}

The correlation coefficient between the measured hydrochemical parameters is presented in Table 4. The correlation of various hydrochemical variables can be classified into different categories such as moderate positive correlation ( $r=0.5$ to 0.79$)$, strong positive correlation $(r>0.80)$, moderate negative correlation $(r=-0.5$ to -0.79$)$ and strong negative correlation $(r>-0.80)[1,14]$. In the present study, WT shows a moderate positive correlation with $\mathrm{Cl}^{-}(p<0.05)$ and $\mathrm{pH}$ showed a moderate negative correlation with DO. Similarly, EC showed a strong positive correlation with TDS $(p<0.01)$, indicating that a probability of a common source of inorganic chemicals and confirming the potential role of TDS on the mobility of the ions in the lake complex. As the concentrations of TDS is directly associated with the EC values, the strong positive correlation between them also confirms the reliable data quality in the study. These correlations are consistent with the CA and PCA results.

\subsection{Comparative analysis}

The comparative assessment of the hydrochemical parameters of waters from the selected lakes is shown in Table 5. In the present study, the highest mean value of EC i.e. $122 \mu \mathrm{S} / \mathrm{cm}$ from the Laxmi Lake and the lowest value $(69 \mu \mathrm{S} / \mathrm{cm})$ from the Kumal Lake, both of which are one of the lowest values as compared to the lakes listed in Table 5. Most of the Himalayan lakes have EC values $<500$ $\mu \mathrm{S} / \mathrm{cm}$, however, some of the lakes have values ranges from 500-1000 $\mu \mathrm{S} / \mathrm{cm}$ (Table 5). Similar to the EC patterns, the TDS concentrations of the present study also revealed one of the least concentrations as compared to the other lakes in the region.
Similarly, the average concentration of $\mathrm{pH}$ of the present study is comparable with most of the Himalayan lakes where it ranges from 7 to 9 . $\mathrm{pH}$ is directly associated with the bicarbonate, carbonate and hydroxide ions in the water. The values of alkalinity in the present study are comparable with many of the freshwater lakes in the regions, as it ranged from 20 to $200 \mathrm{mg} / \mathrm{L}$. The level of alkalinity $<10 \mathrm{mg} / \mathrm{L}$ indicates poorly buffered lakes meaning that these water bodies are the least capable of resisting changes in $\mathrm{pH}$ and therefore, are the most susceptible to problems that occur as a result of acidic pollutants. Moreover, the mean $\mathrm{Cl}^{-}$the content of the present study is also comparable to many of the lakes in the region (Table 5).

$\mathrm{NO}_{3}{ }^{-}$concentrations of the present study showed relatively low mean values and comparable with the many other Himalayan lakes. However, the concentrations of $\mathrm{NO}_{3}{ }^{-}$in the Laxmi Lake reported the second-highest after Pandoh Lake, demonstrating the anthropogenic imprints where there might be some contributions from the Khageri Irrigational Canal and agricultural runoff from the surrounding areas. Relatively higher $\mathrm{NO}_{3}{ }^{-}$and $\mathrm{NH}_{4}{ }^{+}$concentrations in some of the sampling points of the present study may be due to the favorable ecological conditions in the lake complex (e.g., high mean temperature and huge accumulations of organic matters) for rapid mineralization processes of nitrogen-containing compounds and the activities of heterotrophic microorganisms, which is rare in many of the Himalayan lakes. Finally, most of the results of the present study were comparable with the previous studies conducted in the Himalayan freshwater lakes and also within the prescribed range of WHO and NWQGAC guideline values [Tables 1 and 5; [26, 28].
Table 4 Correlation matrix of hydrochemical parameters of the Beeshazar and associated lakes, Chitwan, Nepal

\begin{tabular}{|c|c|c|c|c|c|c|c|c|c|c|c|}
\hline & Tem & $\mathrm{pH}$ & $\mathrm{EC}$ & TDS & $\mathrm{TH}$ & Alk & $\mathrm{Cl}^{-}$ & DO & $\mathrm{NO}_{3}^{-}$ & $\mathrm{PO}_{4}^{3-}$ & $\mathrm{NH}_{4}^{+}$ \\
\hline Tem & 1.00 & & & & & & & & & & \\
\hline $\mathrm{pH}$ & -0.48 & 1.00 & & & & & & & & & \\
\hline EC & 0.27 & 0.07 & 1.00 & & & & & & & & \\
\hline TDS & 0.30 & -0.02 & $0.96^{* *}$ & 1.00 & & & & & & & \\
\hline $\mathrm{TH}$ & 0.44 & 0.17 & -0.30 & -0.28 & 1.00 & & & & & & \\
\hline Alk & -0.32 & -0.25 & 0.10 & 0.17 & 0.43 & 1.00 & & & & & \\
\hline $\mathrm{Cl}$ & $0.56^{*}$ & -0.34 & 0.40 & 0.30 & 0.10 & -0.41 & 1.00 & & & & \\
\hline DO & 0.45 & $-0.59^{*}$ & -0.24 & -0.13 & -0.20 & -0.10 & 0.37 & 1.00 & & & \\
\hline $\mathrm{NO}_{3}^{-}$ & 0.25 & 0.29 & -0.39 & -0.45 & 0.31 & -0.28 & 0.29 & -0.33 & 1.00 & & \\
\hline $\mathrm{PO}_{4}^{3-}$ & 0.27 & -0.11 & -0.05 & 0.02 & 0.37 & 0.04 & -0.08 & -0.07 & 0.20 & 1.00 & \\
\hline $\mathrm{NH}_{4}^{+}$ & -0.01 & -0.10 & -0.19 & -0.21 & -0.19 & 0.14 & 0.15 & 0.05 & 0.08 & 0.30 & 1.00 \\
\hline
\end{tabular}

The bold values indicate significant correlation

*Correlation is significant at the 0.05 level (2-tailed) and ${ }^{* *}$ Correlation is significant at the 0.01 level (2-tailed) 
Table 5 Comparison of hydrochemical variables of the Beeshazar and Associated Lakes with selected lakes of Nepal and India

\begin{tabular}{|c|c|c|c|c|c|c|c|c|}
\hline Lakes & $\mathrm{pH}$ & $\mathrm{EC}$ & TDS & $\mathrm{NO}_{3}^{-}$ & $\mathrm{Cl}^{-}$ & $\mathrm{HCO}_{3}^{-}$ & References & Sampling period \\
\hline Beeshazar & 7.55 & 84 & 50 & 1.75 & 9.02 & 34.4 & Present study & March, 2016 \\
\hline Laxmi & 7.44 & 122 & 61 & 6.26 & 19.1 & 25.3 & & \\
\hline Kumal & 7.55 & 69 & 42 & 1.86 & 9.94 & 25.3 & & \\
\hline Tikauli & 7.53 & 82 & 52 & 1.46 & 12.07 & 25.5 & & \\
\hline Kingfisher & 7.76 & 86 & 52 & 1.02 & 12.78 & 20.3 & & \\
\hline Nagdaha & 7.8 & 195 & 106 & 1.64 & 27.07 & 71.59 & {$[6]$} & December, 2010 and March, 2011 \\
\hline Nainital & 8.7 & 706 & 447 & & 15.3 & 351 & {$[10]$} & Spring season, 2005 \\
\hline Sattal & 9.7 & 119 & 76 & - & 7.3 & 54.4 & & \\
\hline Bhimtal & 8.9 & 181 & 109 & - & 6.4 & 91.1 & & \\
\hline Naukuchiya & 9.4 & 148 & 81 & - & 6.6 & 73.9 & & \\
\hline Renuka & 8.4 & 590 & 378 & - & 11.9 & 146 & {$[11]$} & March-April 2001 \\
\hline Sella & 6.55 & 8.5 & - & 0.7 & 0.5 & 8.5 & {$[12]$} & May, 2011 and November, 2011 \\
\hline Tsokyo Tso & 6.5 & 13 & - & 0.8 & 0.6 & 9.5 & & \\
\hline Rupa & 7.87 & 52 & 37 & 2.46 & 16.52 & - & [13] & June, 2016 \\
\hline Begnas & 9.04 & 36 & 25 & 1.77 & 20.04 & - & & \\
\hline Suraj & 9.1 & 140 & - & 0.13 & 5 & 130 & [14] & August, 2009-October, 2011 \\
\hline Sissu & 8.5 & 200 & - & 4.13 & 56 & 286 & & \\
\hline Deepak & 8.8 & 130 & - & 0.15 & 4.3 & 120 & & \\
\hline Chandra & 8.6 & 180 & - & 0.5 & 3.55 & 150 & & \\
\hline Mansar & 7.99 & 194 & 124 & 0.76 & 6 & 125 & {$[15]$} & October-November, 1998 \\
\hline Betkot & 7.7 & 337 & 168 & 0.06 & 12.2 & 24.92 & [16] & November, 2018 \\
\hline Begnas & 7.7 & 82 & 60 & 6.1 & 4.34 & 17.8 & {$[37]$} & November, 2008; April, 2009 and August, 2009 \\
\hline Pandoh & 7.35 & 72 & 53 & 10 & 1.53 & 43 & [38] & August, 2004; January, 2005 and May, 2005 \\
\hline Phewa & 6 & 43 & - & 0.4 & 1.68 & - & [39] & June, 2015 \\
\hline Jagdishpur & 6.91 & 379 & - & - & 9.65 & 220 & {$[40]$} & Winter, spring, summer and autumn, 2007 \\
\hline Rara & 8.32 & 189 & 95 & 1.63 & 5.79 & 76.16 & [41] & October, 2015 and April, 2006 \\
\hline
\end{tabular}

All the variables are expressed in $\mathrm{mg} / \mathrm{L}$, except $\mathrm{pH}$ and $\mathrm{EC}(\mu \mathrm{S} / \mathrm{cm})$

\subsection{Comprehensive pollution index (PI)}

The PI approach was applied to evaluate the impact of anthropogenic activities and spatial variations in the hydrochemical characteristics on the water quality of the Beeshazar and associated lakes. Based on PI, the water quality level can be categorized into five groups namely cleanness (PI: $\leq 0.20$ ), sub-cleanness ( $\mathrm{PI}: 0.12$ to 0.40 ), slight pollution (PI: 0.41 to 1.0 ), moderate pollution (PI: 1.01 to 2.0) and severe pollution $(\mathrm{PI}: \geq 2.01)$ [27]. Results of the PI are presented in Fig. 5 and showed that the overall sites were found sub-cleanness and slightly polluted, as discussed in the previous study [27]. The PI values of sampling sites in B1, B2, B3, B4, B5, B6, B7, B8, B9, B10, L11, $\mathrm{L} 12, \mathrm{~K} 13, \mathrm{~K} 14, \mathrm{~T} 15, \mathrm{~T} 16$ and KF17 were found to be 0.43 , $0.39,0.40,0.38,0.43,0.36,0.34,0.36,0.36,0.39,0.52,0.51$, $0.45,0.40,0.45,0.39$ and 0.38 , respectively, indicating the lowest pollution in Beeshazar and the highest pollution in the Laxmi Lake. A total of 11 out of 17 sampling sites (B2-B4 and B6-B10) from Beeshazar; and K14, T16 and KF17 from Kumal, Tikauli and Kingfisher, respectively, lied in the sub-cleanness category and the rest of 6 sites (i.e., B1 and B5 from Beeshazar; L11 and L12 from Laxmi; K13 and T15 from Kumal and Tikauli, respectively) have slightly polluted water on the basis of PI analysis. The result can also be justified by the range of the water quality parameters in sampling points of different lakes and the CA results.

\subsection{Water quality index (WQI)}

WQI aims to give a single value to the water quality of a source along with reducing a large number of hydrochemical variables into a simple expression for the easy interpretation of the dataset. The weighted arithmetic water quality index method is widely used to classify the water quality according to the degree of purity and used to determine the suitability of water for drinking purposes. The WQI can be classified into five categories as excellent (0-25); good (26-50); poor (51-75); very poor (76-100); and unsuitable for drinking (>100) [4]. In this study, the WQI score for drinking water was computed using the guidelines of WHO and the WQI of the Beeshazar and 


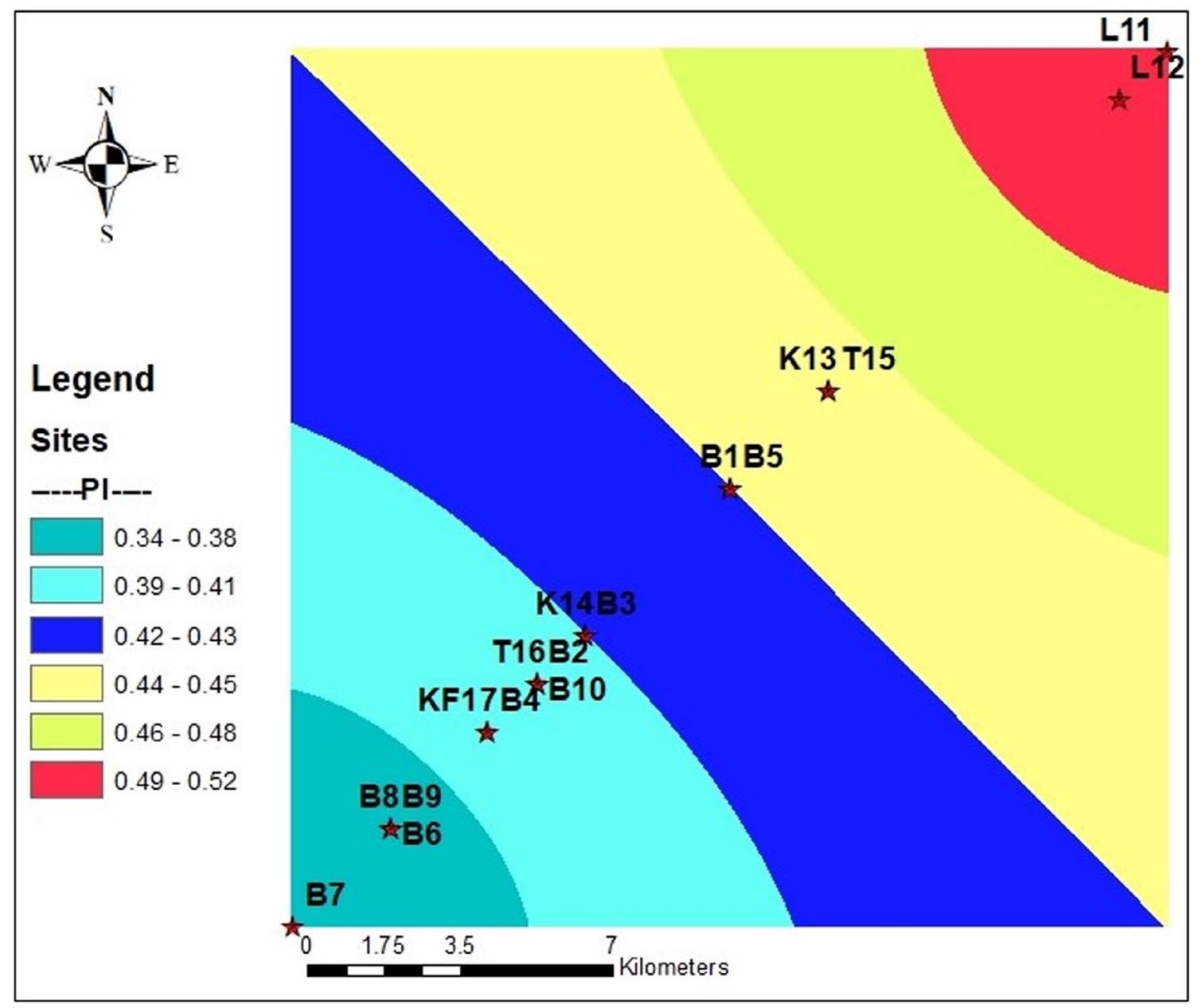

Fig. 5 Spatial distribution of water quality according to comprehensive pollution index (PI) in Beeshazar and associated lakes, Chitwan, Nepal

associated lakes was found to be 33.90 , which lies in the category of good water. Thus, from the WQI, it can be assured that the water quality of the Beeshazar and associated lakes were at a safe level for drinking purposes.

\section{Conclusion}

All the water bodies in the Beeshazar and lake complex are dominated by alkaline water with a mean $\mathrm{pH}$ value of 7.52. The hydrochemistry of the area was impacted by both geogenic and anthropogenic sources and distinct spatial variations were obvious in the lake complex. Moreover, the spatial disparity among the lakes was elucidated from the elevated concentrations of EC, TDS, $\mathrm{TH}, \mathrm{NO}_{3}{ }^{-}$and $\mathrm{PO}_{4}{ }^{3-}$ in the Laxmi Lake. Interestingly, the groundwater inflow nearby the Khageri Irrigation Canal and farmland areas in the vicinity are also suspected as the major contributors to the elevated concentrations of the chemicals in the lake complex.

Comprehensive pollution index marked 11 sampling sites of the study area as sub-cleanness and the rest as slightly polluted, but the overall water quality index of studied lakes was found to be 33.90 , which concludes that the water in the lake complex is currently safe for the drinking purposes. In good agreement with the above, all the analyzed water parameters lie within the prescribed guidelines provided by the WHO and NWQGAC. However, the lake complex is surrounded by intensive farmlands and the anthropogenic signature in terms of elevated concentrations of $\mathrm{NO}_{3}{ }^{-}$and $\mathrm{PO}_{4}{ }^{3-}$ may pose serious problems for retaining water quality in the future.

This study can contribute to the effective use of available water resources with maintaining its natural quality and the results of the study could be considered for the further planning and management of the Ramsar listed lakes in the region. Comprehensive further investigations 
are recommended in the lake complex focusing on hydrogeochemical characterizations at spatiotemporal levels.

Acknowledgements The authors are obliged to the Central Department of Environmental Science, Institute of Science and Technology, Tribhuvan University for providing the necessary support for this research work. The authors are grateful to Mr. Tulashi Dahal, Mr. Narayan Niraula, Mr. Kiran Bishwakarma, Mr. Binod Shrestha and Mr. Dhruba Acharya for their support during data collection and technical part of the manuscript. We are also thankful to Mr. Ramesh Basnet and Ms. Sobita Dhakal for their valuable support in the laboratory analysis. Finally, the authors would like to thank the Editor and anonymous reviewers for their insightful comments and suggestions to polish the manuscript.

\section{Compliance with ethical standards}

Conflict of interest The authors declare that there are no conflicts of interest.

Open Access This article is licensed under a Creative Commons Attribution 4.0 International License, which permits use, sharing, adaptation, distribution and reproduction in any medium or format, as long as you give appropriate credit to the original author(s) and the source, provide a link to the Creative Commons licence, and indicate if changes were made. The images or other third party material in this article are included in the article's Creative Commons licence, unless indicated otherwise in a credit line to the material. If material is not included in the article's Creative Commons licence and your intended use is not permitted by statutory regulation or exceeds the permitted use, you will need to obtain permission directly from the copyright holder. To view a copy of this licence, visit http://creativecommons .org/licenses/by/4.0/.

\section{References}

1. Pant RR, Zhang F, Rehman FU, Wang G, Ye M, Zeng C, Tang H (2018) Spatiotemporal variations of hydrogeochemistry and its controlling factors in the Gandaki River Basin, Central Himalaya Nepal. Sci Total Environ 622:770-782. https://doi.org/10.1016/j. scitotenv.2017.12.063

2. Qaisar FUR, Zhang F, Pant RR, Wang G, Khan S, Zeng C (2018) Spatial variation, source identification and quality assessment of surface water geochemical composition in the Indus River Basin, Pakistan. Environ Sci Pollut Res 25:12749-12763. https:// doi.org/10.1007/s11356-018-1519-Z

3. Cheng G, Li X, Zhao W, Xu Z, Feng Q, Xiao S, Xiao H (2014) Integrated study of the water-ecosystem-economy in the Heihe River Basin. Natl Sci Rev 1:413-428. https://doi.org/10.1093/nsr/ nwu017

4. Tripathee L, Kang S, Sharma CM, Rupakheti D, Paudyal R, Huang J, Sillanpää M (2016) Preliminary health risk assessment of potentially toxic metals in surface water of the Himalayan Rivers. Nepal Bull Environ Contam Toxicol 97:855-862. https://doi. org/10.1007/s00128-016-1945-x

5. Tsering T, Wahed MSA, Iftekhar S, Sillanpää M (2019) Major ion chemistry of the Teesta River in Sikkim Himalaya, India: Chemical weathering and assessment of water quality. J Hydrol Reg Stud 24:100612. https://doi.org/10.1016/j.ejrh.2019.100612

6. Pant RR (2013) Water quality assessment of Nagdaha Lake, Lalitpur. Nepal Perspect Higher Educ 8:52-56
7. Das SK, Routh J, Roychoudhury AN, Klump JV (2008) Major and trace element geochemistry in Zeekoevlei, South Africa: a lacustrine record of present and past processes. Appl Geochem 23:2496-2511. https://doi.org/10.1016/j.apgeo chem.2008.02.011

8. Paudyal R, Kang S, Sharma CM, Tripathee L, Huang J, Rupakheti D, Sillanpää M (2016) Major ions and trace elements of two selected rivers near Everest region, southern Himalayas. Nepal Environ Earth Sci 75:46. https://doi.org/10.1007/s1266 5-015-4811-y

9. Baral U, Ding L, Chamlagain D (2017) Detrital zircon ages and provenance of Neogene foreland basin sediments of the Karnali River section, Western Nepal Himalaya. J Asian Earth Sci 138:98-109. https://doi.org/10.1016/j.jseaes.2017.02.003

10. Das BK (2005) Environmental pollution impact on water and sediments of Kumaun lakes, Lesser Himalaya, India: a comparative study. Environ Geol 49:230-239. https://doi.org/10.1007/ s00254-005-0077-0

11. Das BK, Kaur $P$ (2001) Major ion chemistry of Renuka lake and weathering processes, Sirmaur district, Himachal Pradesh, India. Environ Geol 40:908-917. https://doi.org/10.1007/s002540100 268

12. Deka JP, Tayeng G, Singh S, Hoque RR, Prakash A, Kumar M (2015) Source and seasonal variation in the major ion chemistry of two eastern Himalayan high altitude lakes, India. Arab J Geosci 8:10597-10610. https://doi.org/10.1007/s12517-015-1964-7

13. Pant RR, Pal KB, Adhikari NL, Adhikari S, Dev A (2019) Water quality assessment of Begnas and Rupa Lakes, Lesser Himalaya Pokhara. Nepal J Inst Eng 15(2):116-125. https://doi. org/10.3126/jie.v15i2.27655

14. Singh Y, Khattar JIS, Singh DP, Rahi P, Gulati A (2014) Limnology and cyanobacterial diversity of high altitude lakes of LahaulSpiti in Himachal Pradesh, India. J Biosci 39:643-657. https:// doi.org/10.1007/s12038-014-9458-4

15. Singh O, Rai SP, Kumar V, Sharma MK, Choubey VK (2008) Water quality and Eutrophication status of some lakes of the western Himalayan region (India). In: Proceeding of Taal-2007: the 12th world lake conference, 286:286-291

16. Pant RR, Dhakal TM, Thapa LB, Baral U, Dangol A, Chalaune TB, Pal KB (2019) Water quality assessment of the Betkot Lake. North am acad res, Sudurpaschim Province. https://doi.org/10.5281/ ZENODO.3566682

17. Xu H, Hou Z, An Z, Liu X, Dong J (2010) Major ion chemistry of waters in Lake Qinghai catchments, NE Qinghai-Tibet plateau, China. Quat Int 212:35-43. https://doi.org/10.1016/j.quain t.2008.11.001

18. Shrestha AK, Basnet N (2018) The correlation and regression analysis of physicochemical parameters of river water for the evaluation of percentage contribution to electrical conductivity. J Chem. https://doi.org/10.1155/2018/8369613

19. Singh VB, Ramanathan AL, Mandal A (2016) Hydrogeochemistry of high-altitude lake: a case study of the Chandra Tal, Western Himalaya. India Arab J Geosci 9:308. https://doi.org/10.1007/ s12517-016-2358-1

20. Gautam B, Maskey R, Sapkota RP, Dangol DR (2014) Aquatic macro-invertebrates as bio-indicators: an approach for wetland water quality assessment of Rampur Ghol, Chitwan. Nepal J Inst Sci Tech 19:58-64. https://doi.org/10.3126/jist.v19i2.13853

21. Sharma CM, Kang S, Sillanpää M, Li Q, Zhang Q, Huang J, Tripathee L, Sharma S, Paudyal R (2015) Mercury and selected trace elements from a remote (Gosainkunda) and an urban (Phewa) lake waters of Nepal. Water Air Soil Pollut 226:6. https://doi. org/10.1007/s11270-014-2276-3

22. Lamichhane S, Kandel RC, Pokheral CP, Dahal TP, Bhattarai, S. (2017) Biodiversity profile of Beeshazar and associated lakes, Chitwan. https://www.chitwannationalpark.gov.np/beeshazarl 
akes/images/Biodiversity_Profile_Beeshazar_Tal_2016.pdf. Accessed 10 March 2020

23. Niraula R (2012) Evaluation of the limnological status of Beeshazar Lake, a Ramsar Site in central Nepal. JWARP 2012:256-263. https://doi.org/10.4236/jwarp.2012.45028

24. American Public Health Association (APHA) (2005) Standard methods for the examination of water and wastewater. American Public Health Association. Washington DC

25. Pal KB, Pant RR, Rimal B, Misha AD (2019) Comparative assessment of water quality in the Bagmati River Basin. Nepal ZOOJournal 5:68-78

26. Gorchev HG, Ozolins G (2011) WHO guidelines for drinkingwater quality., WHO chronicle. https://doi.org/10.1016/S1462 -0758(00)00006-6. Accessed 25 March 2020.

27. Zhao Y, Xia XH, Yang ZF, Wang F (2012) Assessment of water quality in Baiyangdian Lake using multivariate statistical techniques. Procedia Environ Sci 13:1213-1226. https://doi. org/10.1016/j.proenv.2012.01.115

28. CBS (2019) Environment Statistics of Nepal 2019. Government of Nepal, National planning commission, Central Bureau of statistics, Thapathali, Kathmandu, Nepal

29. Yu Z, Wu G, Keys L, Li F, Yan N, Qu D, Liu X (2019) Seasonal variation of chemical weathering and its controlling factors in two alpine catchments, Nam Co basin, central Tibetan Plateau. J Hydrol 576:381-395. https://doi.org/10.1016/j.jhydr ol.2019.06.042

30. Haydar CM, Nehme N, Awad S, Koubaissy B, Fakih M, Yaacoub A, Toufaily J, Villeras F, Hamieh T (2014) Water quality of the upper Litani River Basin, Lebanon. Phys Procedia 55:279-284. https:// doi.org/10.1016/j.phpro.2014.07.040

31. Qu B, Zhang Y, Kang S, Sillanpää M (2019) Water quality in the Tibetan Plateau: Major ions and trace elements in rivers of the "Water Tower of Asia." Sci Total Environ 649:571-581. https://doi. org/10.1016/j.scitotenv.2018.08.316

32. Zhang F, Zeng C, Pant RR, Wang G, Zhang H, Chen D (2019) Meltwater hydrochemistry at four glacial catchments in the headwater of Indus River. Environ Sci Pollut Res 26:23645-23660. https ://doi.org/10.1007/s11356-019-05422-5

33. Bhatnagar A, Devi P, George MP (2016) Impact of mass bathing and religious activities on water quality index of prominent water bodies: a multilocation study in Haryana. India Int J Ecol 2016:2915905. https://doi.org/10.1155/2016/2915905

34. Thomas J, Joseph S, Thrivikramji KP (2015) Hydrochemical variations of a tropical mountain river system in a rain shadow region of the southern Western Ghats, Kerala, India. Appl Geochem 63:456-471. https://doi.org/10.1016/j.apgeochem.2015.03.018

35. Paudyal R, Kang S, Sharma CM, Tripathee L, Sillanpää M (2016) Variations of the physicochemical parameters and metal levels and their risk assessment in urbanized Bagmati River, Kathmandu. Nepal J Chem. https://doi.org/10.1155/2016/6025905

36. Varol M, Gökot B, Bekleyen A, Şen B (2013) Geochemistry of the Tigris River basin, Turkey: spatial and seasonal variations of major ion compositions and their controlling factors. Quat Int 304:22-32. https://doi.org/10.1016/j.quaint.2012.12.043

37. Khadka UR, Ramanathan AL (2013) Major ion composition and seasonal variation in the Lesser Himalayan lake: case of Begnas Lake of the Pokhara Valley. Nepal Arab J Geosci 6(11):4191-4206. https://doi.org/10.1007/s12517-012-0677-4

38. Anshumali RAL (2007) Seasonal variation in the major ion chemistry of Pandoh lake, Mamdi district, Himachal Pradesh, India. Appl Geochem 22:1736-1747. https://doi.org/10.1016/j.apgeo chem.2007.03.045

39. Pant RR, Adhikari NL (2015) Water quality assessment of Phewa Lake, Pokhara. Nepal Cogn-A Transdiscip Res J 1(1):130-140

40. Thapa JB, Saud TB (2012) Water quality parameters and bird diversity in Jagdishpur reservoir. Nepal J Sci Tech 13(1):143-155. https://doi.org/10.3126/njst.v13i1.7453

41. Gurung S, Gurung A, Sharma CM, Jüttner I, Tripathee L, Bajracharya RM, Raut N, Pradhananga P, Sitaula BK, Zhang Y, Kang S (2018) Hydrochemistry of Lake Rara: A high mountain lake in western Nepal. Lakes Reserv Res Manag 23(2):87-97. https:// doi.org/10.1111//re.12218

Publisher's Note Springer Nature remains neutral with regard to jurisdictional claims in published maps and institutional affiliations. 